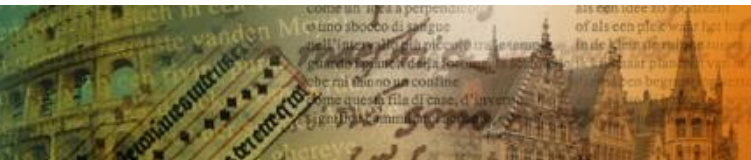

Anno 34, 2019 / Fascicolo 1 / p. 5-18 - www.rivista-incontri.nl - http://doi.org/10.18352/incontri.10282 (C) The author(s) - Content is licensed under a Creative Commons Attribution 3.0 Unported License Publisher: Werkgroep Italië Studies, supported by Utrecht University Library Open Access Journals

\title{
Connecting the peninsula and beyond: Italian intellectual networks of the early modern and modern period An introduction*
}

\section{Floris Meens}

According to the Steirische Völkertafel, an eighteenth-century oil painting by an unknown artist from the Steiermark region in present-day Austria, the Italians were known for their 'astute minds'. Even though the essence of their inward was also described as 'opportunistic', 'voluptuous' and 'underhand' (clearly the opposite of their honourable appearance and their country's pleasant sights), their intellect stood out, especially compared to some of their European counterparts. Whereas Polish intelligence was seen as 'disdainful' and the Hungarian as 'even more so', the Russians lacked intelligence altogether, while the Turks 'or Greeks' were simply rejected as 'dumb'. According to the Völkertafel, while the donkey was obviously the animal that exemplified the Russians, the Italians were represented by the lynx, an animal as mysterious as difficult to catch that was moreover believed to be capable of seeing even through solid objects. When, almost a century before, in 1603, the Italian scientist Federico Angelo Cesi had founded the Accademia dei Lincei, he had also been inspired by the illustration of a lynx on the cover of Magia Naturalis, a work of popular science by Giambattista della Porta, which was first published in Naples in 1558 and in its preface contained the words: 'with lynx-like eyes, examining those things which manifest themselves, so that having observed them, he may zealously use them'.

Maybe these early-modern scholars were also attracted to the lynx's way of life. It might have been quite similar to theirs, as it preferred to live on its own, but occasionally chose a small group for travelling and hunting. Similarly, some Renaissance Italian scholars were well aware that to make their scholarly lives flourish they also depended on others, and therefore on their networks. As Simone Testa has so brilliantly exposed in his monograph on early-modern Italian academies, Della Porta and Cesi were certainly not the only scholars to use the metaphor of an animal to describe their intellectual activities. The Sienese humanist Scipione Bargagli (15401612), for instance, indicated the importance of scholarly collaboration by comparing

\footnotetext{
* This theme issue is the result of a one-day symposium on Italian intellectual networks organised in December 2017 at Radboud University (NL). I would like to show my gratitude to Radboud University's Institute for Historical, Literary and Cultural Studies for offering financial support as well as accommodation. I also would like to thank the board of the WIS, the Dutch Working Group for Italian Studies (Werkgroep Italië Studies), for its willingness to co-organise the symposium; to the editors of its peer-reviewed and internationally acclaimed journal, Incontri, for offering the opportunity to publish this theme issue; and to my colleagues who were willing to present and publish their research here.
} 
the members of learned academies to bees. ${ }^{1}$ Even if these early-modern intellectuals were obviously not familiar with terms like networks and networking they seem to have been well aware of their importance.

Maybe spurred by the historical representation of Italy as a country of lynx-like people with astute minds, but certainly also by its unique (heritage of) intellectual life and culture, in the last few decades scholars have begun to unveil the manifold manifestations and effects of intellectual networks in Italy. They have analysed their role and functioning during the medieval period, ${ }^{2}$ the Renaissance, ${ }^{3}$ and the Enlightenment, ${ }^{4}$ as well as their role in Italy's modern history, including its unification, ${ }^{5}$ the liberal period, ${ }^{6}$ the fascist era, ${ }^{7}$ and the post-war years. ${ }^{8}$

This theme issue presents some new research that illustrates this recent interest in Italian intellectual networks. Before delving deeper into the three words that make up the title of this publication and before summarising its content to clarify what this issue sets out to do, let me ensure what it does not. Even though the articles collected here focus on a variety of periods and study networks that relate to various regions of the Italian peninsula, together they can obviously not present an exhaustive diachronic account of the history of Italian intellectual networks. They do, however, address some

\footnotetext{
1 S. Testa, Italian Academies and Their Networks, 1525-1700. From Local to Global, London, Palgrave Macmillan, 2015, p. 23.

2 For instance: S. Steckel, N. Gaul \& M. Grünbart (eds.), Networks of Learning. Perspectives on Scholars in Byzantine East and Latin West, c. 1000-1200, Berlin, Lit Verlag, 2014; G. Seche, Libro e società in Sardegna tra Medioevo e prima età moderna, Firenze, L.S. Olschki, 2018.

3 For instance: Testa, Italian Academies, cit.; J. Everson, D. Reidy \& L. Sampson (eds.), The Italian Academies, 1525-1700. Networks of Culture, Innovation and Dissent, Abingdon-New York, Legenda, 2016; E. Goudriaan, Florentine Patricians and their Networks: Structures behind the Cultural Success and the Political Representation of the Medici Court (1600-1660), Leiden, Brill, 2018; C. Celenza, The Intellectual World of the Italian Renaissance: Language, Philosophy, and the Search for Meaning, Cambridge, Cambridge University Press, 2015; G. Fragnito \& A. Tallon (eds.), Hétérodoxies croisées et controverses doctrinales entre France et Italie, XVle-XVIle siècles, Rome, École Française de Rome, 2015; M. Goldish, 'Rabbi Abraham Rovigo's Home as a Center for Traveling Scholars', in: F. Bregoli, C. Ferrara degli Uberti \& G. Schwarz (eds.), Italian Jewish Networks from the Seventeenth to the Twentieth Century. Bridging Europe and the Mediterranean, Cham, Palgrave Macmillan, 2018, pp. 25-38.

${ }^{4}$ For instance: J. Boutier, B. Marin \& A. Romano (eds.), Naples, Rome, Florence. Une histoire comparée des milieux intellectuels italiens (XVIle-XVIIle siècles), Rome, Publications de l'École Française de Rome, 2005.

${ }^{5}$ For example: M. Isabella, Risorgimento in Exile. Italian Émigrés and the Liberal International in the Post-Napoleonic Era, Oxford, Oxford University Press, 2009; N. Urbinati, 'Intellectuals', in: E. Jones \& G. Pasquino (eds.), The Oxford Handbook of Italian Politics, Oxford, Oxford University Press, 2015, pp. 594-608; E. Noether, 'The Intellectual Dimension of Italian Nationalism: An Overview', in: History of European Ideas, 16, 4-6 (1993), pp. 779-784.

${ }^{6}$ For instance: P. Allagrezza, L'élite incompiuta. La classe dirigente politico-amministrativa negli anni della destra storica (1861-1876), Milano, A. Giuffrè, 2007; M. Gervasoni, L'intellettuale come eroe: Piero Gobetti e le culture del Novecento, Milano, La Nuova Italia, 2000; A. Banti, Storia della borghesia Italiana. L'età liberale, Roma, Donzelli Editore, 1996; M. Spinella \& A. Arensi (eds.), Gli intellettuali nella storia dell'Italia unita, Milano, Nicola Tetie Editore, 1987.

${ }^{7}$ For example: Urbinati, 'Intellectuals', cit.; G. Bonsaver, 'Culture and Intellectuals', in: R.J.B. Bosworth (ed.), The Oxford Handbook of Fascism, Oxford, Oxford University Press, 2010, pp. 109-126; D. La Penna, 'Habitus and Embeddedness in the Florentine Literary Field: The Case of Alberto Carocci (1926-1939)', in: Italian Studies, 73, 2 (2018), pp. 126-141; G. Sedita, Gli intellettuali di Mussolini. La cultura finanziata dal fascismo, Firenze, Le Lettere, 2010; A. Gregor, Mussolini's Intellectuals: Fascist Social and Political Thought, Princeton, Princeton University Press, 2005; S. Pugliese, Fascism, Anti-fascism, and the Resistance in Italy, 1919 to Present, Lanham, Rowman \& Littlefield Publishers, 2004.

${ }^{8}$ For example: M. Milani, 'Impegno, national and transnational identities in Il Politecnico and Sud (19451947)', in: Modern Italy, 21, 2 (2016) (special issue: National Dialogues and Transnational Exchanges across Italian Periodical Culture, 1940-1960), pp. 157-170; F. Guidali, Uomini di cultura e associazioni intellettuali nel dopoguerra tra Francia, Italia e Germania occidentale (1945-1946), dissertation Freie Universität Berlin \& Università degli Studi di Milano, 8 November 2013.
} 
important questions that have not yet been answered, and from a variety of perspectives suggest new directions that lead us to interesting answers.

\begin{abstract}
Networks
Studying social networks is hardly revolutionary. Already in the 1930s social network analysis emerged as an important tool for the analysis of the connections between systems and the spreading of ideas within larger groups of people. ${ }^{9}$ As David Easley and Jon Kleinberg have argued, social network analysis as a methodological framework was an amalgam of approaches from a variety of disciplines:
\end{abstract}

From computer science and applied mathematics has come a framework for reasoning about how complexity arises, often unexpectedly, in systems that we design; from economics has come a perspective on how people's behaviour is affected by incentives and by their expectations about the behaviour of others; and from sociology and the social sciences have come insights into the characteristic structures and interactions that arise within groups and populations. The resulting synthesis of ideas suggests the beginnings of a new area of study, focusing on the phenomena that take place within complex social, economic, and technological systems. ${ }^{10}$

In the 1930s the psychosociologist Jacob Moreno was the first to create a sociogram, visualising social relationships between people with dots and lines. Based on the Hungarian mathematician Dénes König's graph theory, Frank Harary, R.Z. Norman and Dorwin Cartwright then published ground-breaking research on the potential positive and negative effects of network structures on human relationships. The 1940s and 1950s also saw a group of Harvard researchers including A.R. Radcliffe-Brown and Émile Durkheim giving new direction to the analysis of social relations by researching the formation of cliques: 'an informal association of people among whom there is a degree of group feeling and intimacy'. ${ }^{11}$ Publications on exchange theory and elite theory followed. At the same time anthropologists created a new model that pointed out the major impact of conflict and change in both social life of tribes and villages. Among them, John Barnes was the first to use the term 'social network' (as well as 'web') by which he meant 'the whole of social life' as opposed to 'partial networks', all interhuman contact in the informal sphere. ${ }^{12}$ His colleague J. Clyde Mitchell introduced the notion of 'ego-centric' networks, consisting of social contact not related to institutional structures, network 'density' (the extent to which all possible relations are actually present) and 'reachability' (how easy it is for people to contact one another through a limited number of steps). ${ }^{13}$

During the 70s, Mark Granovetter, an American sociologist, published 'The Strength of Weak Ties', a theory by which he aimed to explain the spread of information in social networks. Studying the connections between networks, his conclusion was that many networks are connected by weak ties (indicating casual acquaintances), and that human beings with many weak ties are best suited to spread information. ${ }^{14}$ During the same period, the Dutch anthropologist Jeremy Bossevain in

\footnotetext{
9 I have here summarized parts of Baird's overview of the history of social network analysis: I. Baird, 'Introduction. Social Networks in the Long Eighteenth Century: The Public Sphere Revisited', in: eadem (ed.), Social Networks in the Long Eighteenth Century: Clubs, Literary Salons, Textual Coteries, Newcastle upon Tyne, Cambridge Scholars Publishing, 2014, pp. 1-30.

10 See also: D. Easley \& J. Kleinberg, Networks, Crowds and Markets. Reasoning about a Highly Connected World, New York-Cambridge, Cambridge University Press, 2010, p. XI.

${ }^{11}$ Baird, 'Introduction', cit., p. 7.

12 Ivi, p. 8.

13 J. Smith, Social Network Analysis. A Handbook, London, Sage Publications, 2000 (second edition), p. 32.

${ }^{14}$ M. Granovetter, 'The Strength of Weak Ties', in: American Journal of Sociology, 78, 6 (1973), pp. 1360-

1380; see also: Baird, 'Introduction', cit., p. 9.
} 
his work further explained the complex ways in which interhuman relationships are forged and structured, but also the ways that individuals try to manipulate these to attain goals, by shaping and influencing the dynamics of coalitions. Rethinking the concept of 'primary groups' that had been coined already in 1909 by the American sociologist Charles Cooley, ${ }^{15}$ Bossevain distinguished between primary social networks of personal relations, and secondary, comprising more formalised relations with representatives of institutions. ${ }^{16}$ Bossevain regarded individuals as social entrepreneurs with their own agency, being able to use existing relationships in many ways but also to activate old out-of-date connections, and to forge new. ${ }^{17}$ Bossevain was particulary interested in studying those who had become 'highly expert networking specialists', whom he called brokers: 'a broker is a professional manipulator of people and information who brings about communication for profit', here obviously not (only) to be understood in terms of money. ${ }^{18}$ Moreover he termed the messages sent between individuals 'social transactions', and all things exchanged with social value, including information or help, 'transactional content'. And while according to Bossevain most exchange is reciprocal, he also revealed examples of serious imbalances, leaving some indebted to others. ${ }^{19}$

As we will see in some of the articles collected here, both Granovetter's and Bossevain's ideas still hold ground, even though there have been some major additions. Since the turn of the twentieth century, for instance, two major ground-breaking concepts have been coined by the Hungarian-American physicist Albert-László Barabási: 'preferential attachment' (the tendency of nodes to link themselves to hubs that have the most connections) and 'fitness' (fitter nodes attract more links at the expense of less fit nodes). ${ }^{20}$

In 2004, overseeing the tradition that social network analysis had become, the American structuralist sociologist Linton Freeman concluded that a great variety of scholars were now using it, including sociologists, anthropologists, economists, political scientists, psychologists, communication scientists, organizational behaviour and market specialists, and physicists. ${ }^{21}$ While, according to Freeman, most of them focus on networks that connect individual human beings, some of them prefer studying the networks that link institutions or groups. In any case, thinking about applying a social network approach one should realise that it 'is grounded in the intuitive notion that patterning of social ties have important consequences for those actors. Network analysts, then, seek to uncover various kinds of patterns, and they try to determine the conditions under which those patterns arise, and to discover their consequences'. ${ }^{22}$

In recent decades various scholars have also shown interest in the history of social networks and in the analysis of historical social networks. This has most certainly been the result of the aforementioned establishment of the study of social contact and exchange as an important topic in the social sciences. ${ }^{23}$ Historians of knowledge, for instance, who for a long time had been tracing the 'origins, decay and renewal of

\footnotetext{
${ }^{15}$ C. Cooley, Social Organization, New York, Charles Scribner's sons, 1909, pp. 23-31.

$16 \mathrm{~J}$. Bossevain, Friends of Friends. Networks, Manipulators and Coalitions, New York, St. Martin's Press, 1974 , p. 148.

${ }^{17}$ For the contribution of Bossevain to the field of social network analysis see: C. Kadushin, Understanding Social Networks. Theories, Concepts, and Findings, Oxford, Oxford University Press, 2012, p. 57.

18 Ibidem.

${ }^{19}$ Cfr. Goudriaan, Florentine Patricians, cit., p. 229.

20 Baird, 'Introduction', cit., pp. 9-10.

21 L. Freeman, The Development of Social Network Analysis. A Study on the Sociology of Science, Vancouver, Empirical Press, 2004, p. 5.

22 Ivi, p. 2.

${ }^{23}$ C. Reijen \& M. Rensen, 'Introduction', in: idem (eds.), European Encounters: Intellectual Exchange and the Rethinking of Europe (1914-1945), Amsterdam-New York, Rodopi, 2014, pp. 13-32.
} 
institutions, or weighed the work of individuals against long-range traditions', became interested in studying learning as a social practice, which inevitably meant revealing the interconnectedness between, and the agencies of individuals, social groups and institutions. Networks became an omnipresent concept in their work, as it helped them to visualise the mutual connections between individual scholars and institutionalized intellectual as well as non-intellectual structures. ${ }^{24}$

The network as a metaphor for interhuman relationships was also introduced to the field of cultural transfer studies. While in many of their seminal texts from the late 1980s Michel Espagne and Michael Werner studied (historical) processes of transfer between nations in terms of sender/receiver, ${ }^{25}$ more recently scholars have been revealing the complexity of and reciprocity in processes of transfer in both peripherical and border regions. ${ }^{26}$ In 2002 Werner and Bénédicte Zimmermann presented histoire croisée, ${ }^{27}$ a new method that 'bundles existing historical approaches which stress the perspective of the contemporaries, interwoven human relations and their balances of power and self-reflexivity'. ${ }^{28}$ While many recent publications in the fields of cultural transfer, some of them by applying histoire croisée, reveal the cultural mediator 'active across linguistic, artistic and geocultural borders' as 'the central carrier of cultural transfer', many also indicate that (their) (intellectual) networks were pivotal in this process. ${ }^{29}$

The method of analysing historical networks has moreover changed quite drastically with the burgeoning of the Digital Humanities. An ambitious and important example has been the large Stanford-based 'Mapping the Republic of Letters' project, ${ }^{30}$ which includes subprojects on the Grand Tour, that analyses the routes, people and places that made up the Grand Tour of Europe and Italy in particular; ${ }^{31}$ as well as on salons, which charts the intellectual and social geography of European salons between 1700-1914. ${ }^{32}$ Another wonderful initiative has been a four-year project on The Italian Academies, 1525-1700, which resulted in an online catalogue with data of some 500 academies from across the Italian peninsula. ${ }^{33}$

This overview of the history of (historical) network analysis shows that we are dealing with a vibrant and active interdisciplinary field. It has, however, not yet provided us with a clear definition of the term network. Although there are many possible answers, most scholars would agree with the one provided by the British

\footnotetext{
24 S. Steckel, 'Networks of Learning in Byzantine East and Latin West: Methodological Considerations and Starting Points for Further Work', in: Steckel, Gaul \& Grünbart (eds.), Networks of Learning, cit., p. 191. 25 For instance: M. Espagne \& M. Werner, 'Deutsch-französischer Kulturtransfer im 18. und 19. Jahrhundert. Zu einem neuen interdisziplinären Forschungsprogramm des C.N.R.S.', in: Francia: Forschungen zur westeuropäischen Geschichte, 13, 1 (1985), pp. 502-510; M. Espagne \& M. Werner, 'La construction d'une référence culturelle allemande en France: genèse et histoire (1750-1914)', in: Annales. Économies, Sociétés, Civilisations, 42, 4 (1987), pp. 969-992.

${ }^{26}$ Reijen \& Rensen, 'Introduction', cit., p. 21.

${ }^{27}$ M. Werner \& B. Zimmermann, 'Vergleich, Transfer, Verflechtung. Der Ansatz der histoire croisée und die Herausforderung des Transnationalen', in: Geschichte und Gesellschaft, 28 (2002), pp. 606-636; M. Werner \& B. Zimmermann (eds.), De la comparaison à l'histoire croisée, Paris, Éditions du Seuil, 2004. ${ }^{28}$ P. van Dam, 'Vervlochten geschiedenis: hoe "histoire croisée" de natiestaat bedwingt', in: Tijdschrift voor Geschiedenis, 125, 1 (2012), p. 96.

29 R. Meylaerts, L. D’hulst \& T. Verschaffel (eds.), Cultural Mediation in Europe, 1800-1950, Leuven, Leuven University Press, 2017, p. 7.

30 http://republicofletters.stanford.edu (13 January 2019). For some of its outcomes: M. Comsa, M. Conroy, D. Edelstein, C. Summers Edmondson \& C. Willan, 'The French Enlightenment Network', in: The Journal of Modern History, 88 (2016), pp. 495-534.

31 https: //classics.stanford.edu/projects/grand-tour-project (13 January 2019).

32 http: //blogs.memphis.edu/salonsproject/ (13 January 2019). For some of its outcomes: F. Meens, 'How to Approach Salons? A Fin-de-siècle Italian Case Study', in: Cultural and Social History, 15 (2018), pp. 184, https: //doi.org/10.1080/14780038.2018.1427356.

33 http://italianacademies.org (13 January 2019).
} 
sociologist John Scott: 'the term network refers to individuals (or more rarely collectivities and roles) who are linked together by one or more social relationships, thus forming a social network. Examples of relationship links include kinship, communication, friendship, authority and sexual contact'. ${ }^{34}$

\section{Intellectual networks}

Now we know more about the definition and the academic tradition of studying (historical) social networks, it is time to determine what should count as an intellectual network. Let us therefore analyse and dissect the epithet. The philosopher and historian of political thought Norberto Bobbio, who as a public intellectual played a major role in Italian political life himself, reminds us that even this questioning what essentially is an intellectual, turns ourselves into one:

[È] naturale che [gli intellettuali] scrivano su se stessi. Se non fossero loro ad occuparsi di se stessi, chi lo farebbe? E se altri scrivesse di loro non diventerebbe, per il solo fatto di scrivere, un intellettuale? Diventa un intellettuale anche se si mette a scrivere sugli intellettuali per dirne tutto il male possibile [...]. È un destino cui non si sfugge, non appena ci si pone il problema di che cosa sono gli intellettuali. Chi si pone questo problema diventa, per il solo fatto di porselo, un intellettuale, cioè uno che non fa cose ma riflette sulle cose, non maneggia oggetti ma simboli, i cui strumenti di lavoro non sono macchine ma idee. ${ }^{35}$

Etymologically the term "intellectual" has its roots in the Latin word intellectus (discernment, understanding), a noun-use of the past participle of the verb intelligere (to discern, understand). The Old French intellectuel, dating from the thirteenth century, referred to someone 'grasped by the understanding (rather than by the senses)'. The English synonym intellectual was first used during the fourteenth century. ${ }^{36}$

Both French and English synonyms were, however, hardly practiced until the nineteenth century. During the early modern period other terms were used far more often to describe intellectual life, its main actors and their qualities. Most of them had, however, another meaning than nowadays. Maria Stuiber has demonstrated the Begriffsgeschichte of both German and Italian vocabulary commonly used to indicate intellectual culture by analysing dictionaries. The word erudite, for instance, had no entry of its own in the 1612 first edition of the Vocabolario degli Accademici della Crusca, the first dictionary which aimed to establish a foundation and norm for the use of Italian. The verb erudire was only used in Latin to offer explanations of other Italian words. The first time the Italian verb was part of the Crusca's vocabulary was during the eighteenth century, but only very briefly (as erudirsi, to get learned), especially in contrast to letterario and related notions including letterato and letteratore. During that time lettere and letteratura were synonyms for knowledge and erudition, while letterato was defined as 'scienziato, che ha lettere'. In sum, in early-modern Italy erudito, letterato, and scienziato all referred to those who were learned. Moreover, the present-day difference between the natural sciences (scientia) and the humanities (eruditio) was lacking altogether. ${ }^{37}$ But Stuiber also notices that the eighteenth century saw the upcoming of the ideal of Bildung and its Italian equivalent

\footnotetext{
34 J. Scott, A Dictionary of Sociology, Oxford, Oxford University Press, 2014, pp. 511-512.

${ }^{35} \mathrm{~N}$. Bobbio, Il dubbio e la scelta, Intellettuali e potere nella società contemporanea, Roma, Carocci, 1993, pp. 113-114. I warmly thank my colleague Tamara van Kessel for suggesting this quote.

36 Online Etymology Dictionary, https: / /www.etymonline.com/word/intellectual (13 January 2019).

37 M. Stuiber, Zwischen Rom und dem Erdkreis. Die gelehrte Korrespondenz des Kardinals Stefano Borgia (1731-1804), Berlin, Akademie Verlag, 2012, pp. 13-22.
} 
coltura as a new kind of learnedness in between 'Fachgelehrsamkeit' and 'Schriftlosigkeit', which was not depended on formal, institutionalized education. ${ }^{38}$

It was only during the later stages of the nineteenth century that the term "intellectual" became fashionable. Christophe Charle in his landmark publication Naissance des intellectuels, 1880-1900 studied the conditions that led to the appearance of the French notion of 'intellectuels'. According to Charle we must see this neologism as the answer to the late nineteenth century disbalance in literary and intellectual professions between the growing number of candidates and the shortage of positions. The increasing number of individuals who, as a result of the fierce competition, were being rejected created not only a buoyant cultural expansion, but also a crisis in the representations (including le savant, l'homme des lettres) of the world they had been eager to but failed to enter. As Charle argues '[t]his crisis expressed the flattering social image of the liberal and intellectual professions and the social depreciation brought about by the influx of newcomers whom this social image only victimized'. ${ }^{39}$ The neologism intellectuel was then coined by those who saw themselves as different and sometimes even as the only representatives of the real elite, to denote their ideal and to strengthen their professional intellectual positions even more, as well as to provide a collective identity for social engagement. ${ }^{40}$

By and large the term "intellectual" not only became a notion of individuals and groups that were eager to distinguish themselves from others, it also became a sociological typology. As Richard Bellamy has pointed out in his study on Italian intellectuals and politics:

Intellectuals appear in different guises in different times and places. Scholars have attempted numerous typologies: priests and jesters, insiders and outsiders, interpreters and legislators, pure and revolutionary, mandarins and samurai, populists and Olympians, expert advisers and rebellious gadflies, to mention only a few [...]. Each is revealing though none appears wholly satisfactory. The factors determining an intellectual's stance are manifold, often highly contingent, and can interact in so many diverse ways that generalizations rarely illuminate more than the particular cases from which they were derived. Ideology, epistemology, individual temperament, the form of government and type of society within which the intellectual operates and his or her position within them, political circumstances, popular reactions - to differing degrees these and other elements can all play a part. Neither profession nor social class unites intellectuals as a group: they have been philosophers, novelists, poets, scientists, academics, journalists and clerics, well-educated aristocrats and self-taught labourers. Though they share a vocation to speak intelligently about matters of public concern, the claims they make for knowledge and its power have varied greatly. ${ }^{41}$

The articles assembled here all use the word intellectual in its broader sociological sense, and use it to indicate all the above forms of learnedness. Moreover, the phrase intellectual network will be used to describe both networks of intellectuals, as well as networks of intellectual exchange. We will thus witness scholarly debates on a variety of topics. Moreover we will encounter old and young, left and right, avant-garde as well as well-established scientists, artists, poets, novelists, journalists, politicians and salonnières, most of them belonging to the comparatively small educated classes. ${ }^{42}$

\footnotetext{
38 Ivi, pp. 17-18.

${ }^{39}$ C. Charle, Birth of the Intellectuals, 1880-1900, Cambridge, Polity Press, 2015, p. 146.

${ }^{40}$ C. Charle, Naissance des intellectuels, Paris, Les Éditions de Minuit, 1990, pp. 38-65; see also: G. Eyal \& L. Buchholz, 'From the Sociology of Intellectuals to the Sociology of Interventions', in: Annual Review of Sociology, 36 (2010), p. 125.

${ }^{41}$ R. Bellamy, 'From philosophes to pundits: Italian intellectuals and politics from Vico to Eco', in: Journal of Modern Italian Studies, 6, 2 (2001), p. 151. See also: J. Jennings \& A. Kemp-Welch, Intellectuals in Politics. From the Dreyfus Affair to Salman Rushdie, London-New York, Routledge, 1997.

${ }^{42}$ Charle, Birth of the Intellectuals, cit., p. 4.
} 
Inspired by the work of Gisèle Sapiro, we understand their intellectual world 'non comme un espace désincarné qui ne se déploierait que dans le ciel des idées mais comme un univers social formé d'agents, individus et institutions, lesquels constituent autant de médiations justiciables d'une analyse sociohistorique'. ${ }^{43}$ All the articles therefore reveal these networks as an essential part of the social conditions of intellectual life, and, to refer to the work of Pierre Bourdieu, especially as carriers of intellectual import and export. ${ }^{44}$ They reveal how Italian intellectual networks were forged, how this involved processes of social inclusion and exclusion, how these networks worked, what they did, if and how they conformed to an intellectual ethos, ${ }^{45}$ and if and how its historical actors reflected on these aspects, for instance by naming their networks.

\section{Italian intellectual networks}

The final question is obviously what we consider to be an Italian intellectual network. There are four, sometimes overlapping criteria. First there are networks whose actors refer to it as Italian. Contrary to claims of anachronistic reasoning, this was true already before the Italian peninsula was politically unified. As John Brewer shows in his article the geologists and mineralogists he analyses "were resolutely local. But this did not preclude a strong sense that what the savants were producing was "Italian" science.' Brewer cites Giacinto Carena (1778-1859), whose ideal was to create 'a free and easy scientific and literary communication among the diverse parts of our Italy'.

Obviously not all representatives of the networks studied here used the word "Italy" to describe their intellectual pursuits. The second criterion is therefore more obvious: most of the network analysed in the articles manifested itself on the Italian peninsula, even though some of their members and activities lead us to Poland (Tamara van Kessel), Germany (Floris Meens) and Mexico (Matthijs Jonker).

Then there are networks whose actors preferred Italian as their main communicative language. During the early modern period there was a strong relationship between the academies that sprouted all over the Italian peninsula and the use of the Italian language. In the sixteenth century members of several learned bodies in Tuscany worked hard to make their own dialect into a language shared by all Italians. The fact that they debated a lot about the need for a common language had everything to do with the problems they faced trying to disseminate their ideas in the linguistically divided peninsula. ${ }^{46}$ Indeed, other academies, including those related to the Church in Rome, fostered the use of Latin. ${ }^{47}$ During the seventeenth and eighteenth century many foreigners were attracted to Italy, many of them visiting the country as part of their Grand Tour. Some of them were or at least thought of themselves as learned and became part of Italy's academies and their networks. ${ }^{48}$ Many of them used French as their main academic language, partly the result of the revocation of the Edict of Nantes and the consequent diaspora of the Huguenots, partly also of the

\footnotetext{
${ }^{43}$ G. Sapiro, 'Introduction', in: eadem (ed.), L'espace intellectuel en Europe. De la formation des Étatsnations à la mondialisation XIXe-XXIe siècle, Paris, La Découverte, 2009, p. 10.

44 P. Bourdieu, 'Les conditions sociales de la circulation internationale des idées', in: Sapiro (ed.), L'espace intellectuel en Europe, cit., pp. 27-39.

${ }^{45}$ Sapiro, 'Introduction', cit., p. 25.

${ }^{46} \mathrm{M}$. Sherberg, 'The Accademia Fiorentina and the Question of the Language: The Politics of Theory in Ducal Florence', in: Renaissance Quarterly, 56, 1 (2003), pp. 26-55.

47 M.P. Donato, 'Accademie e accademismi in una capitale particolare', in: Mélanges de l'École française de Rome. Italie et Méditerranée, 111, 1 (1999), pp. 415-430. For the development and early-modern use of Latin, see: S. Knight \& S. Tilg (eds.), The Oxford Handbook of Neo-Latin, Oxford-New York, Oxford University Press, 2015; J. Bloemendal, Latijn. Cultuurgeschiedenis van een wereldtaal, Amsterdam, Athenaeum-Polak \& Van Gennep, 2016.

48 J. Black, Italy and the Grand Tour, New Haven-London, Yale University Press, 2003.
} 
adaptation of French as the most important diplomatic language (instead of Latin) from the Treaty of Rastatt (1714) onwards. ${ }^{49}$ Just like elsewhere in Europe, French thus became an important means of intellectual communication on the Italian peninsula. ${ }^{50}$ The importance of French gained momentum when Napoleon was crowned Italian king in 1805. It remained strong in the wake of his defeat, because the Italian unification was accomplished only in the later stages of the nineteenth century. This also meant that the Church could still effectively promote the use of Latin. Moreover, the attractiveness that Italy and Rome in particular still possessed to foreigners made their languages (and especially German given the high amount of German archaeologists working in Italy) a force to reckon with as well. ${ }^{51}$ While during the Fin de siècle Italian was used by many who worked on the Italian peninsula, it still faced fierce competition from other languages. And the major changes in European academia that came with the First World War also affected Italy. German, which had risen in importance from 1870 onwards and even would be the only language to beat English in terms of numbers of publications between 1880 and 2015, lost its position due to the course of the war and the rise of Nazism. ${ }^{52}$ English became the unthreatened academic lingua franca. While many Italian intellectuals for long held on to their own mother language as well as to the use of German and French, even for them English eventually became inevitable. ${ }^{53}$

A fourth and final criterium to call an intellectual network Italian is if it was initiated by or had strong ties to the Italian nation state. During the early-modern period intellectual culture was of course essentially international. As Victor Karady has argued, up until the Reformation, Western European scholars were united as the result of the Catholic Church's domination over universities. And even if during the earlymodern period science by and large became a political tool that could manifest royal power, the cultures of Humanism and Enlightenment, and especially the Republic of Letters, were as internationally oriented as had been the premodern universities. ${ }^{54}$ Indeed, Karady's point is confirmed in the articles presented here by Matthijs Jonker, Martijn van Beek and John Brewer.

For more recent times, however, Bourdieu reminds us that:

[o]n croit souvent que la vie intellectuelle est spontanément internationale. Rien n'est plus faux. La vie intellectuelle est un lieu, comme tous les autres espaces sociaux, de nationalismes et d'impérialismes et les intellectuels véhiculent, presque autant que les autres, des préjugés, des stéréotypes, des idées reçues, des représentations très sommaires, très élémentaires, qui se nourrissent des accidents de la vie quotidienne, des incompréhensions, des malentendus, des blessures (celles par exemple que peut infliger au narcissisme le fait d'être inconnu dans un pays étranger). ${ }^{55}$

\footnotetext{
${ }^{49}$ M. Gordin, Scientific Babel: How Science Was Done Before and After Global English, Chicago, Chicago University Press, 2015, p. 31; M. Fumaroli, When the World Spoke French, New York, New York Review Books, 2001, p. XVIII;

50 P. Musitelli, 'Artisti e letterati stranieri a Roma nell'Ottocento. Strutture, pratiche e descrizioni della sociabilità', in: Memorie e Ricerca, 46 (2014), pp. 27-44.

${ }^{51}$ F. Meens, 'De wetenschapstaal van de Eeuwige Stad', in: Ex Tempore, 36, 2 (2017), pp. 116-130.

52 Gordin, Scientific Babel, cit., p. 7.

${ }^{53}$ M. Pallottino, 'Introduzione. Un centro mondiale di cultura umanistica: l'Unione Internazionale degli Istituti di Archeologia, Storia e Storia dell'arte in Roma', in: P. Vian (ed.), Speculum Mundi. Roma centro internazionale di ricerche umanistiche, Roma, Unione Internazionale degli Istituti di Archeologia, Storia e Storia dell'Arte, 1993, pp. 9-15.

54 V. Karady, 'L'émergence d'un espace européen des connaissances sur l'homme en société : cadres institutionnels et démographiques', in: Sapiro (ed.), L'espace intellectuel en Europe, cit., pp. 43-68.

${ }^{55}$ Bourdieu, 'Les conditions sociales de la circulation internationale des idées', cit., p. 28.
} 
Indeed, during the nineteenth century tensions rose between academia's internationalistic and nationalistic tendencies. This was of course the age of the nation states, but also of the differentiation of science into various fields and the professionalization of the intellectual professions. These fields of study were not identical in all countries, and the process of nationalising academic life strongly influenced the features of all fields in different nation-states. Indeed, culture and science in particular were key elements in the formation of the nation state. Its new political order gained authority, meaning and prestige not only by claiming the monopoly over the rightful employment of violence, but also by taking over control over intellectual production. ${ }^{56}$ Nationalism did, however, not exclude international intellectual culture. On the contrary; one only has to think of the many conferences, colloquiums, shared projects, academic journals, and the ever-increasing (both unforced and forced) mobility of scholars. ${ }^{57}$ Universities were instrumental in showing the high qualities of national culture. Even the increasing intellectual globalization that characterized academic life during this period, including student and staff exchange, became a proof to the nation's excellence, making internationalisation part or even a strategy of 'high nationalisation'. ${ }^{58}$

Thus, as Christophe Charle, Jürgen Schriewer and Peter Wagner have argued, higher education and research became characterized by 'persistent contradiction between localizing and universalizing influences', ${ }^{59}$ to which intellectuals needed to relate. Some of them reacted strongly against the internationalisation 'for the sake of cultural identity and self-assertion', ${ }^{60}$ and became the prophets of the modern political order, including its fierce competition with foreign nations. ${ }^{61}$ Others defended internationalism as a 'higher form of knowledge', to open up intellectual debates, to gain prestige and strengthen one's position within the national field, and/or to break with and to present itself as an antagonism of what they saw as 'national parochialism'. ${ }^{62}$

After the First World War some regarded cooperation even as the best way to prevent more bloodshed, which resulted in the foundation of the important International Institute of Intellectual Cooperation (1924). But in many countries, including Italy, the influence of nationalist cultural politics was still strongly felt in academic life. And indeed, especially since and because of the fascist takeover, philosophers as well as scholars of political thought have debated the relationship between the (Italian) nation-state and intellectuals, thereby also contesting the role of their networks. ${ }^{63}$ Some of the articles presented here will further elaborate on these issues (Brewer's for the beginning of the Risorgimento, Meens's for the postRisorgimento liberal phase, and both de Haan's and van Kessel's for the fascist period).

\footnotetext{
56 P. Wagner, 'Introduction to Part I', in: C. Charle, J. Schriewer, \& P. Wagner (eds.), Transnational Intellectual Networks. Forms of Academic Knowledge and the Search for Cultural Identities, FrankfurtNew York, Campus, 2004, pp. 17-25.

57 Sapiro, 'Introduction', cit., pp. 5-25.

58 C. Charle, J. Schriewer \& P. Wagner, 'Editors Preface', in: idem (eds.), Transnational Intellectual Networks, cit., p. 12.

59 Ibidem; Cfr. Sapiro, 'Introduction', cit., p. 15.

${ }^{60}$ Ivi, p. 13; Cfr. Wagner, 'Introduction to Part l', cit., p. 17.

61 Sapiro, 'Introduction', cit., pp. 5-25.

62 Ivi, p. 13; Wagner, 'Introduction to Part l', cit., p. 17.

63 Bonsaver, 'Culture and Intellectuals', cit.; Sedita, Gli intellettuali, cit.; Gregor, Mussolini's Intellectuals, cit.; Pugliese, Fascism, Anti-fascism, and the Resistance, cit.; Urbinati, 'Intellectuals', cit. But also: R. Bellamy, Croce, Gramsci, Bobbio and the Italian Political Tradition, Colchester, Ecpr Press, 2014.
} 
Italian intellectual networks: a diachronic perspective

It has become clear that combining the terms into Italian intellectual networks allows us to get a better understanding of an important part of the history of Italian intellectual life. Let me conclude this introduction by presenting an overview of the articles and by sketching a few of their main questions and some directions of thought.

The articles assembled here deconstruct a large variety of intellectual networks, ranging from those related to individual actors to those linked with institutions. There has been an academic tendency to especially investigate the networks of well-known great figures (mostly male) as well as their role in the networks of others. Even if most of the networks discussed here also centre around men (with the exception of those analysed by Meens and van Kessel), ${ }^{64}$ many of these protagonists nowadays are not that well-known anymore. Obviously, moreover, the authors bring into relief the many outcomes of these networks, including the dissemination (as well as reshaping) of ideas, knowledge and beliefs; the circulation of goods including books, works of art, and gifts (Jonker, van Beek and Brewer in particular); and especially the underlying processes of the ratification or contestation of political, cultural, intellectual and socio-economic hegemonies.

Even more important than their outcomes, however, is how these networks worked in a variety of political, social and economic contexts. How were they built, shaped and maintained? What did one have to do in order to become a member? What was the role of markers of identity, including gender, age, class, wealth, belief, etc. in the development of these networks? What were the individual or group-specific motives for taking part? What modes of communication were used, and which institutions involved? How important were specific kinds of (private, semi-private or public) sociability and social settings, including salons, academies, clubs, libraries, conferences, etc.? How large or small was the agency of the individuals? Did they always play according to codes of a shared intellectual ethos, or did they counter these? How much space did they have to manipulate and manoeuvre? In a way, answering these questions also contributes to the demystification of intellectual networks. Building and maintaining them was not easy, and many things could and did go wrong. Delving deeper into the counteractive forces, rivalries, contestations, failures and unintended consequences might provide new insight into their functioning and will enable us to further historicize the complex and ambiguous process of intellectual networking.

The essays collected here tackle these issues from a variety of perspectives and by using a variety of methods. They are written by art historians, ancient historians, literary scholars, as well as specialists of the early modern and modern periods. While most of them use qualitative approaches to the study of intellectual networks, a more quantitative perspective is provided as well (Meens). This issue offers a diachronic outlook on the history of Italian intellectual networks, starting in the Renaissance and ending in the Fascist period.

In the opening article Matthijs Jonker focuses on Rome's aforementioned famous Accademia dei Lincei as a network and cultural broker in the publication of the Tesoro messicano, the first collective natural history project in Europe carried out on

\footnotetext{
64 It is encouraging to see the number of publications on intellectual networks of women steadily grow. See, for instance: V. Cox, 'Members, Muses, Mascots. Women and the Italian Academies', in: Everson, Reidy \& Sampson, The Italian Academies 1525-1700, cit., pp. 132-167; N.M. Filipini (eds.), Donne sulla scena pubblica. Societa e politica in Veneto tra Sette e Ottocento, Milano, FrancoAngeli, 2006; M. Betri \& E. Brambilla (eds.), Salotti e ruolo femminile in Italia tra fine Seicento e primo Novecento, Venezia, Marsilio, 2004; L. Rischbieter, Henriette Hertz. Mäzenin und Gründerin der Biblioteca Hertziana in Rom, Stuttgart, Steiner, 2004; S. Dyson, Eugénie Sellers Strong: Portrait of an Archaeologist, London, Duckworth, 2004.
} 
encyclopedic scale. The material was gathered by the Spanish physician, Francisco Hernández (ca. 1515-1587), during a scientific expedition in Mexico between 15711577. After his return to Spain, his manuscripts were edited and abridged by another royal physician, the Italian Nardo Antonio Recchi (ca. 1540-1594). He brought his compendium, together with hundreds of color images that had been copied from Hernández's originals, to his fatherland in 1589 on his appointment as first physician of the kingdom of Naples. After obtaining the compendium the Lincei began to prepare its publication immediately. It still took forty years until a definitive version of the Tesoro was published in 1651. Jonker analyses this project as a prime example of the collective nature of the Lincean scientific pursuits. He demonstrates that the publication of a scientific treatise depended on the contribution and collaboration (and thus on a well-functioning network) of various scholars, and especially studies their relevance in the patronage, knowledge, artistic and publication practices that were essential for the compilation and publication of this specific work of science.

In his contribution Martijn van Beek addresses the functioning of the network of the Order of Saint Benedict on the Italian peninsula at the end of the seventeenth century. By analysing six drawings of the Madonna by Juan Ricci de Guevara (16001681), van Beek demonstrates that both in theory and practice Benedictine intellectual scholarly activity was always combined with practicing faith. This combination becomes manifest in the art and writings of Ricci de Guevara, a visual artist, eminent scholar and a fanatic traveller. As van Beek shows, Ricci's drawings are manifestations of his critical stance towards Aquinas' remarks concerning devotion to Mary. For him the popular devotion to Mary outweighed the intellectual theological restrictions. A recurring argument in Ricci's criticism was the divine experience by devote artists while creating an image of Mary. Ricci re-enacted this practice in his drawings that were based on popular images of the Madonna that he came across during his travels in Italy. His merge of devotion and scholarship led Ricci to the conclusion that in the creation of these images it was possible to worship Mary's divinity. Thus van Beek reads Ricci's drawings as a visual manifestation of the Benedictine intellectual network in which scholarly activity and practicing faith were naturally combined.

John Brewer in his article focusses on the network of the volcanologist Teodoro Monticelli (1759-1845), who, although hardly mentioned in the histories of science, was a powerful figure in his day. Brewer demonstrates that Monticelli was both part of local knowledge traditions as well as the larger academic community. Using three overlapping but distinct (inter)national networks, reaching from Naples to London, Monticelli aimed to realize his clear views on the future of Naples. This included the establishment of constitutional regimes with an educated and enfranchised public, and sometimes even the unification of the entire peninsula, as well as the promotion of his hometown as a modern scientific centre. Monticelli knew that his passion for mineralogy, geology and volcanism (and especially his love for, and knowledge and collections of the Vesuvius) could serve him well. Focusing on Monticelli's dependency on his networks, Brewer analyses how they worked. Apart from the exchange of books, periodicals and proceedings of local academies, Monticelli was in correspondence with like-minded amateur and professional scholars. He also welcomed them in Naples, making them part of its academic culture by showing them around on the Vesuvius, informing them through accounts of its activity and exhibiting samples. Then there was intellectual and gift exchange. For a man that probably never travelled outside the Italian peninsula himself, Monticelli was responsible for a quite impressive number of itineraries of travelling specimen dispatched to and from all different parts of Europe and even beyond. Brewer concludes that in all of these strategies, Vesuvius was indispensable, as it offered Monticelli the social and cultural resources to pursue his cause, as well as that it protected him during the many regime changes. 
In the fourth contribution Floris Meens traces the genesis as well as the development of the salon of the Roman countess and archaeologist Ersilia CaetaniLovatelli (1840-1925). Continuing the tradition of her father, the politician, artist and scholar Michelangelo Caetani, Ersilia began welcoming her scholarly friends during the late 1860s. Many of them became involved in the politics of the young Italian nationstate because they were appointed senator for life. During the 1870s CaetaniLovatelli's intellectual gatherings not only became regular, they also became a crucial hotspot of Rome's and Italy's political life. Meens's analysis of this salon is twofold. On the one hand, by using a quantitative approach as well as by analysing its practicalities and ethos, he discloses the countess's networking politics. By focusing on the salon's political conversation on the other, and especially its debates on the young Italian nation-state and its political state of affairs, he reveals its political meaning and influence on liberal Italy.

The theme of politics has a strong presence in the two final articles as well. As the article by Meens already indicates, intellectuals and their networks played an important role in the initiatives, both from within the Italian government as well as from outside, to shape Italy into a modern nation state and to culturally unite its population. Questioning the role of the "foreign" in this process, Tamara van Kessel in her article demonstrates how networks engaged intellectuals from Italy as well as abroad in the construction of "Italy". She delves into the history of the Dante Alighieri Society, founded in $\mathbf{1 8 9 9}$ to promote the Italian language and culture in other countries via a complex network of local committees within and outside the Italian peninsula. The Dante functioned as a public platform for intellectuals to question how Italy was to be shaped and represented. Focusing on the Fascist period, but bearing in mind its roots in the liberal period and remarking that the transition from intellectuals serving to build Italy as a new nation-state and those promoting Fascism was not always unambiguous, van Kessel studies the case of the Dante Alighieri Society's committee in Warsaw. Referring to Mario Isnenghi's concept of the 'intellectual functionary' she uncovers the main goals of the Warsaw Dante Committee members as well as how they related to the Fascist government and ideology. Analysing the connections of the Warsaw Dante committee to other examples of internationalism in the interwar period that offered a platform for nationalist ideas and agendas, van Kessel not only clarifies the role of foreign Italian intellectual networks in the creation of an image of Italy, but also the ways in which the Fascists implemented international cultural policy to strengthen their position.

In the final article Nathalie de Haan traces the rich life and manifold activities of Umberto Zanotti-Bianco (1889-1963), an Italian social activist, antifascist, self-made archaeologist and senatore a vita. As a networker pur sang, Zanotti was able to successfully employ a great variety of activities with the help of influential and/or rich persons. Zanotti's ultimate objective was the regeneration of the South, and education, culture, history, and heritage were all instrumental to that. Focusing on the period 1907-1941, the year of his imprisonment in Rome followed by prolonged periods of internal exile, de Haan traces Zanotti's involvement in both the National Association for the Interests of the Mezzogiorno in Italy as well as the Società Magna Grecia. As becomes clear in de Haan's analysis of how Zanotti built, managed and used his partly overlapping and constantly changing networks, he was well aware of their potential. Despite his strong anti-fascist position, he collaborated with persons within fascist institutions (despite the fact that his real intimates were opponents of Mussolini's regime and that he cut off some of the contacts that did not provide any help), and these contacts provided him with some room to operate. Even if sometimes the authorities severely obstructed his activities, de Haan agrees with van Kessel in arguing that the fascist regime was never a monolithic block and did not always react 
in a coherent way. Zanotti knew well how to use this room for 'wheeling and dealing'. But in the end his networks could not prevent his imprisonment in 1941, a proof of the regime's repression reaching its peak. De Haan interprets the various internal exiles imposed on Zanotti as attempts to isolate him, by which the Italian authorities themselves implicitly emphasised the great influence of intellectual networks.

\section{Keywords}

Networks, intellectuals, Italy, cultural exchange, transfer

Floris Meens is assistant professor of Cultural History at Radboud University. His research interests include the history of networks, as well as the history of music and emotions.

Radboud Universiteit Nijmegen

Institute for Historical, Cultural and Literary Studies

P.O. Box 9103

6500 HD Nijmegen (The Netherlands)

f.meens@let.ru.nl 